\title{
Profil Darah Rusa Totol (Axis axis) Betina Sehat di Pusat Inovasi Agroteknologi (PIAT), Universitas Gadjah Mada
}

\section{Haematological Profile of Healthy female Spotted deer (Axis axis) at The Center for Agrotechnology Innovation, Universitas Gadjah Mada}

\author{
Dhirgo Adji ${ }^{1 *}$, Dian Astuti ${ }^{2}$ \\ ${ }^{1}$ Fakultas Kedokteran Hewan,Universitas Gadjah Mada, \\ Jl. Fauna No. 2, Karangmalang Yogyakarta \\ ${ }^{2}$ Fakultas Peternakan, Universitas Gadjah Mada, \\ Jl. Fauna No. 3, Karangmalang Yogyakarta \\ Email: inaorthovet@google.com
}

Naskah diterima: 11 September 2017, direvisi: 15 Juli 2018, disetujui: 19 Oktober 2019

\begin{abstract}
Center for Agrotechnology Innovation, Gadjah Mada University (PIAT), one of the place for development and breeding ground of spotted deer in Yogyakarta, Indonesia. The study of blood profiles was intended to allow veterinarian to understand the normal profile of the spotted deer. Fifteen healthy spotted deers belonging to PIAT were used as experimental animals. The deers were drawn its blood through the jugular vein without the use of anaesthesia. Blood was then accommodated in an EDTA tube, centrifuged at 2500 RPM and analyzed using a Mindray BC-2800 haematology analyzer machine. Based on the results of the study of the blood it were known that Haemoglobine $(\mathrm{Hb})$ was: $11.5 \pm 1.703 \mathrm{~g} / \mathrm{dl}$, Red blood cells (RBC) was: $9.3 \pm 3.58010^{6} / \mu \mathrm{l}$, Packed cell volume (PCV) was: $30.8 \pm 6.035 \%$, Mean corpuscular Volume (MCV) was: $36.8 \pm 11.102 \mathrm{fl}$, Mean corpuscular haemoglobine $(\mathrm{MCH})$ was: $15.0 \pm 7.313 \mathrm{pg}$, Mean corpuscular haemoglobine concentration (MCHC) was: 40.0 $\pm 14.657 \mathrm{~g} / \mathrm{dl}$, White blood cells (WBC) was: $6.4 \pm 3.09610^{3} / \mu 1$, Neutrophils was: $43.4 \pm 21.646, \%$ Basophils was: $0.2 \pm 0.168 \%$, eosinophils was: $0.4 \pm 0.447 \%$, lymphocytes was: $53.4 \pm 21.546 \%$ and monocytes was: 2.6 $\pm 2.394 \%$. From all of the datas it indicated that blood profiles of PIAT's spotted deers are different from similar spotted deer blood profiles in India.
\end{abstract}

Key words: PIAT; Blood profiles; spotted deer; Gadjah Mada University; Mindray BC 2800

\begin{abstract}
Abstrak
Pusat Inovasi Agroteknologi, Universitas Gadjah Mada (PIAT), salah satunya menjadi tempat perkembangan dan penangkaran rusa totol di Yogyakarta, Indonesia. Kajian tentang profil darah dimaksudkan agar petugas kesehatan hewan memahami gambaran darah rusa totol yang dikembangkan di Indonesia. Lima belas ekor rusa totol betina milik PIAT dipergunakan sebagai hewan coba. Rusa diambil darahnya melalui vena jugularis tanpa menggunakan anestesi. Darah ditampung pada tabung Ethilen diamine tetra acetic acid (EDTA), disentrifus dengan kecepatan 2500 RPM dan di analisis menggunakan mesin hematologi analyzer merk Mindray seri BC2800. Berdasarkan hasil kajian diketahui $\mathrm{Hb}: 11,5 \pm 1,703 \mathrm{~g} / \mathrm{dl}, \mathrm{RBC}: 9,3 \pm 3,58010^{6} / \mu 1, \mathrm{PCV}: 30,8 \pm 6,035 \%$,

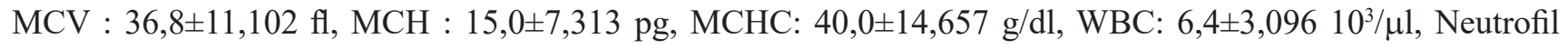
: 43,4 $\pm 21,646 \%$, Basofil: 0,2 $\pm 0,168 \%$, eosinofil : 0,4 $\pm 0,447 \%$, limfosit : 53,4 $\pm 21,546 \%$ dan monosit : $2,6 \pm 2,394 \%$. Hasil tersebut menunjukkan bahwa gambaran darah rusa totol yang ditangkarkan di PIAT, berbeda dibandingkan dengan gambaran darah rusa serupa yang ada di India.
\end{abstract}

Kata kunci: PIAT; Profil darah,;rusa totol; Universitas Gadjah Mada; Mindray BC 2800 


\section{Pendahuluan}

Rusa totol (cheetal) atau lazim disebut spotted deer (Axis axis) adalah spesies rusa asli India dengan jantan berukuran tinggi $90 \mathrm{~cm}$ dan betina $70 \mathrm{~cm}$ dengan berat rata rata jantan $30-75 \mathrm{~kg}$ dan betina 24-45 kg (Rajagopal et al., 2010). Rusa totol (spotted deer) saat ini banyak dipelihara di taman taman nasional dan penangkaran di Indonesia . Rusa Totol di PIAT dipelihara dalam upaya Universitas Gadjah Mada untuk ikut mengembangbiakkan rusa asli India ini dengan model pemeliharaan semi modern. Untuk saat ini rusa totol di PIAT baru berjumlah 56 ekor terdiri dari rusa jantan, betina dan anakan rusa. Pakan harian rusa terdiri dari rumput gajah, ketela rambat dan konsentrat dengan air disediakan secara ad libitum. Populasi yang meningkat akan sangat memungkinkan rusa dimanfaatkan tidak hanya sebagai hewan eksotik, namun, juga sangat mungkin dikembangkan menjadi hewan produksi daging, kulit maupun tanduk. Problematika rusa di area peternakan maupun penangkaran adalah sulitnya pengamatan terhadap hewan yang mengalami sakit. Hampir tidak ada perbedaan perilaku rusa yang sakit dan sehat apabila diamati dari kejauhan, karena bila kondisi masih belum terlalu parah, rusa masih akan selalu bergerak mengikuti kelompoknya. Pemahaman tentang profil darah rusa totol menjadi sangat penting artinya bagi Dokter Hewan atau petugas kesehatan hewan di PIAT . Elarabany (2018) menjelaskan bahwa pemahaman tentang kondisi sehat hewan, status nutrisi, kualitas hidup dapat diketahui dengan baik melalui tinjauan terhadap profil darah hewan yang bersangkutan, termasuk rusa totol. Standardisasi normal profil darah rusa totol baik jantan maupun betina di PIAT sampai saat ini masih belum banyak diketahui. Profil standar normal rusa totol tersebut sangat penting artinya untuk mengevaluasi perubahan fisiologis maupun patologis hewan. Pada kajian ini pembanding diambilkan dari kajian yang sudah dilakukan di Chennai, kota di sebelah selatan India dan Uttar Pradesh, kota bagian utara India.

\section{Materi dan metode}

Lima belas ekor rusa totol betina sehat, umur rata-rata dua tahun, diseleksi dari penangkaran rusa milik PIAT Universitas Gadjah Mada, Yogyakarta. Hewan yang dinyatakan sehat setelah dilakukan pemeriksaan fisik dan pemeriksaan terhadap adanya cacing dalam feses, hewan di manipulasi tanpa menggunakan obat obatan. Satu per satu hewan diambil darahnya dari vena jugularis sebanyak $2 \mathrm{ml}$, ditampung dalam tabung yang mengandung antikoagulan EDTA. Tabung yang berisi darah selanjutnya di sentrifuse pada kecepatan 2500 rpm selama 10 menit, dipisahkan antara plasma sel darahnya, dan disimpan dalam refrigerator suhu $4^{\circ} \mathrm{C}$. Pengambilan darah tanpa menggunakan sarana anestesi karena dikawatirkan akan mempengaruhi nilai profil darah yang dimaksud. Dua puluh mikro liter sampel darah yang diambil dari sampel yang sudah dipersiapkan diatas dimasukkan dalam tabung kaca dipergunakan untuk melihat profil darah secara otomatis sesuai dengan metoda kerja spesifik mesin analisis darah Mindray seri BC 2800. Karakteristik hematologis seperti ; sel darah merah (RBC), hemoglobin ( $\mathrm{Hb})$, packed-

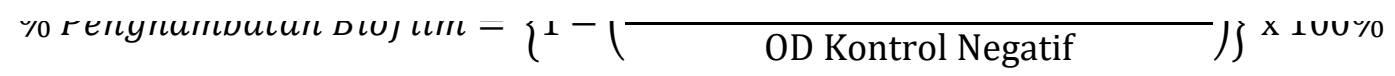

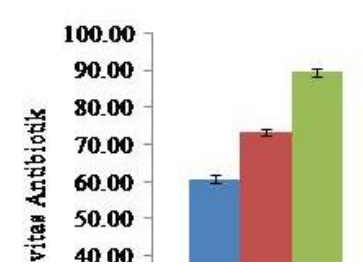

Gambar 1. Rusa betina yang dipergunakan dalam penelitian

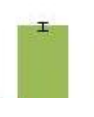

Gambar 2. Teknik pengambilan darah rusa melalui vena jugularis 
cell volume (PCV), mean corpuscular volume (MCV), mean corpuscular Hemoglobin (MCH), mean corpuscular hemoglobin concentration (MCHC), sel darah putih (WBC) serta diferensial leukositnya (eosinofil, basofil, neutrofil, limfosit dan monosit).

Untuk mengetahui kondisi profil darah yang diperoleh merupakan angka normal, selain dipilih hewan sehat dengan tingkah laku normal, juga dibuat perbandingan menggunakan angka profil darah dari rusa totol hasil penelitian di India (Chennai dan Uttar Pradesh).

\section{Hasil dan Pembahasan}

Data laboratorik bisa diinterpretasikan dalam bentuk populasi maupun individual dan sangat penting untuk monitoring spesies hewan liar. Variabel darah juga dapat menjadi sarana memprediksikan program program survival maupun translokasi (Mathews et al., 2006). Telah dipahami bersama bahwa data hematologis sangat bervariasi tergantung dari jenis kelamin, umur, waktu pengambilan sampel, faktor fisiologis, lokasi geografis, status nutrisi dan metoda restrain yang dilakukan saat pengambilan sampel. Beberapa dari faktor tersebut berinteraksi sehingga menghasilkan data yang bervariasi (Elarabany, 2018)

Di daerah India, rusa jenis totol yang ditangkarkan mendapat suplai makanan untuk keseimbangan gizinya berupa hijauan berbagai jenis rumput rumputan, sayuran seperti kobis dan wortel serta konsentrat dan vitamin-mineral premix (Azaad et al., 2005). Di Indonesia, pakan rusa totol bisa berupa rumput paitan (Axonopus compressus) dan rumput teki (Cyperus rontudus) dengan beberapa tambahan yang berupa konsentrat, sayuran, dedaunan, dan umbi umbian (Hasnawati et al., 2006)

Tidak ada gejala klinis yang menggambarkan sakit pada semua rusa yang dipergunakan dalam penelitian ini, baik sebelum, selama dan sesudah penelitian. Tidak ada individu yang menderita sakit maupun kematian pasca perlakuan. Pada Tabel 1 terlihat bahwa profil darah pada rusa totol milik PIAT berbeda dengan hasil pemeriksaan darah yang dilakukan di India. Parameter hemoglobin dan sel darah merah bisa dikatakan lebih tinggi dibandingkan dengan darah rusa di Chennai, namun mirip dengan rusa yang berasal dari Uttar Pradesh. Jumlah Sel darah merah rusa totol milik PIAT berada pada kisaran lebih baik dibanding rusa Uttar Pradesh namun lebih rendah dibanding rusa Chennai. Angka PCV sedikit lebih rendah bila dibandingkan dengan rusa Chennai maupun Uttar Pradesh. Nilai MCV, MCH dan MCHC dari rusa milik PIAT lebih baik dari pada rusa yang berasal dari Chennai namun lebih rendah bila dibandingkan rusa Uttar Pradesh. Angka leukosit beserta differensialnya hampir sama dengan rusa totol Chennai maupun Uttar Pradesh. Nilai $\mathrm{Hb}$ yang meningkat sangat jarang terjadi, tingginya nilai hemoglobin biasanya berhubungan dengan gangguan fungsi paru maupun jantung atau kompensasi kadar oksigen darah yang rendah dalam waktu yang lama (Weiss and Wardrop, 2011). Mean Corpuscular Volume (MCV) yang meningkat biasanya karena terdapat sel sel dalam ukuran besar pada kasus kehilangan darah kronis sehingga sel darah muda dilepaskan dalam sirkulasi (Weiss and Wardrop, 2011). Mean Corpuscular hemoglobin $(\mathrm{MCH})$ bila mengalami peningkatan menandakan adanya hemolisis sedangkan bila menurun terkait adanya anemia kronis dan defisiensi Fe (Harvey, 2001). Angka total leukosit pada darah rusa yang berasal dari PIAT lebih tinggi dibandingkan dengan leukosit total rusa Chennai namun relatif lebih rendah dibanding leukosit rusa dari Uttar Pradesh. Leukosit dan differensial dari rusa milik PIAT lebih tinggi dibandingkan dengan rusa dari Chennai namun lebih rendah dari rusa Uttar Pradesh. Gejala klinis tidak menunjukkan adanya sakit atau gangguan inflamasi pada hewan yang dipergunakan sebagai hewan coba. Tidak ada hasil analisis leukosit yang menunjukkan angka di atas $20.000 \mu$ l. Jika terdapat angka yang berada pada rerata lebih tinggi dibandingkan dengan leukosit rusa Chennai, karena dalam pengambilan sampel darah, rusa PIAT tidak menggunakan sarana anestesi atau obat obatan yang membuat tenang. Mayoritas peningkatan leukosit disebabkan oleh respon keradangan baik lokal maupun sistemik (Stockham and Scott, 2008). Adanya agen infeksi seperti bakteri, virus, ricketsia, jamur, protozoa dan parasit. Beberapa peningkatan pada rusa sangat mungkin terjadi terkait sifat rusa yang mudah sekali stress. Rasa 
Tabel 1. Profil darah Rusa Totol PIAT dibandingkan data hewan sejenis di Chennai dan Uttar Pradesh India.

\begin{tabular}{lccc}
\hline \multicolumn{1}{c}{ PROFIL DARAH } & $\begin{array}{c}\text { Axis axis } \\
\text { (PIAT) }\end{array}$ & $\begin{array}{c}\text { Axis axis* } \\
\text { (Chennai) }\end{array}$ & $\begin{array}{c}\text { Axis axis }{ }^{* *} \\
\text { (Uttar Pradesh) }\end{array}$ \\
\hline Hb (g/dl) & $11.5 \pm 1.703(8.5-15.5)$ & $8.5-12.5$ & $11-12.5$ \\
RBC (10 \%l) & $9.3 \pm 3.580(6.4-15)$ & $11-15$ & $4.6-6.2$ \\
PCV (\%) & $30.8 \pm 6.035(21.4-36.5)$ & $33-36$ & $32-38$ \\
MCV (fL) & $36.8 \pm 11.102(23.1-58.9)$ & $24-30$ & $61.5-69.5$ \\
MCH (pg) & $15.0 \pm 7.313(7.7-29.6)$ & $7.03-8.33$ & $20.2-23.9$ \\
MCHC (g/dl) & $40.0 \pm 14.657(27.1-72.4)$ & $24.29-34.72$ & $3-3.4$ \\
Leukosit (10 ${ }^{3 / \mu l)}$ & $6.4 \pm 3.096(3.9-13.9)$ & $3.5-5.1$ & $8-10$ \\
Eosinofil (\%) & $0.4 \pm 0.447(0-1.3)$ & $1-3$ & $2-3$ \\
Basofil (\%) & $0.2 \pm 0.168(0-0.5)$ & $0.0-0.0$ & $0.0-0.0$ \\
Neutrofil (\%) & $43.4 \pm 21.646(21.4-81.2)$ & $48-56$ & $30-32$ \\
Limfosit (\%) & $53.4 \pm 21.546(15-73.9)$ & $41-47$ & $48-51$ \\
Monosit (\%) & $2.6 \pm 2.394(0.4-3.1)$ & $1-4$ & $0-4$ \\
\hline
\end{tabular}

* Sahoo and BM Arora (2002), Indian J. Anim Sci. 72 (9) : $762-765$

** Shanti et al. (2012), Tamilnadu J. Vet. Animal Sci 8 (6) 351 - 355

cemas yang meningkat akibat penangkapan hewan akan memicu peningkatan glukokortikoid endogen yang menyebabkan peningkatan jumlah sel darah putih (Feldman et al., 2000).

Gambaran darah makhluk hidup berbeda satu sama lain. Meskipun berasal dari spesies, namun kisaran tinggi-rendahnya sangat tergantung atas beberapa faktor antara lain manajemen pemeliharaan, pakan dan jumlah pakan yang diberikan, umur, jenis kelamin, ras, status kesehatan, metoda koleksi darah, teknik hematologi yang dipergunakan, lingkungan, suhu badan, dan status fisiologisnya (Tibbo et al., 2004). Berdasarkan hasil yang peneliti peroleh, terbukti bahwa meskipun pada spesies hewan yang sama, namun karena cara pemeliharaan, pakan yang diberikan dan cara pengambilan sampel darah berbeda, akan menyebabkan hasil yang diperoleh juga berbeda. Kim et al.. (2015) menyatakan bahwa ketidakseimbangan nutrien dalam pakan yang dikonsumsi, baik berupa unsur yang berlebihan atau kekurangan akan mempengaruhi gambaran darah hewan. Pada penelitian ini, status nutrisi baik rusa PIAT maupun rusa pembanding dari India tidak ditentukan dan hanya merupakan nilai kondisi apa adanya, mengingat hewan yang akan dilihat gambaran darahnya adalah hewan liar yang tidak mudah ditangkap. Dalam kondisi status nutrisi yang sama,terdapat kemungkinan bahwa profil darah rusa yang di analisis adalah sama atau hampir sama.

\section{Kesimpulan}

Profil darah rusa totol betina di PIAT memiliki karakteristik yang berbeda dengan data gambaran darah rusa totol yang diteliti di daerah India.

\section{Ucapan terima kasih}

Penulis mengucapkan terimakasih kepada Pusat Inovasi Agroteknologi Universitas Gadjah Mada, yang telah mengijinkan penggunaan rusa untuk penelitian serta Kementrian Riset Teknologi dan Pendidikan Tinggi, yang telah memberikan dana melalui skema penelitian PUPT untuk pelaksanaan penelitian ini.

\section{Daftar Pustaka}

Asher, G. W., A. J. Peterson, J., and Bass, J. (1989). Seasonal pattern of $\mathrm{LH}$ and testosterone secretion in adult male fallow deer (Dama dama). J. Reprod. Fertil. 85, 657-665.

Azad, M.M., Hossain and Bhuiyan, A.K.F.H. (2005). Feeding and Management of Spotted Deer at Dhaka Zoo. Int. J. Zool Res, 1: $48-52$. 
Elarabany, N. (2018). A comparative study of some haematological and Biochemical Parameters between two species from the Anatidae family within migration season. $J$. Bas. Appl. Zool, vol. 79, Article No: 31.

Feldman, B.F., Zinkl, J.G., Jain, N.C. (2000). Schalm's Veterinary Hematology 5th ed. Lippincott, Williams and Wilkins, Philadelphia.

Harvey, J.W. (2001). Atlas of Veterinary Hematology: Blood and Bone Marrow of Domestic Animals. WB Saunders Company, Philadelphia.

Hasnawati, Hadi, S., Alikodra, Mustari A.H. (2006). Analisis Populasi dan Habitat Sebagai Dasar Pengelolaan Rusa Totol (Axis axis) di Taman Monas Jakarta. Media Konservasi Vol XI, No 2, 46-51.

Kim,K., Terrence, Vance, T.M. and Chun, O.K. (2015). Greater Total Antioxidant Capasity from Diet and Supplements Is associated with a less Atherogenic Blood Profile in U.S. Adults.Nutrients 2016, 8(1), 15.

Matthews, L. R., Cook, C.J. (1991). Deer welfare research Ruakura findings. Proceedings of a Deer Course for Veterinarians (Wilson, P. R., Ed.). Deer Branch Course 8. 353-366.

Mathews, F., D. Moro, R. Strachan, M. Gelling, and Buller, N. (2006). Health surveillance in wildlife reintroductions. J. Biol. Conserv.131, 338-347.
Sahoo and Arora,B.M. (2002),Haematological and blood biochemical profile of spotted deer (Axis axis) reared in semicaptive environment.Indian J. Anim. Sci. 72 (9) : 762-765.

Shanti , G., Balasubramanyam, D., Thangaraju,P., Srinivasa, R. (2012). Hematological Studies In Indian Deer, Tamilnadu J. Vet. Anim. Sci. 8 (6) $351-355$.

Stockham, S.L. and Scott, M.A. (2008). Fundamentals of Veterinary Clinical Pathology, 2nd ed. Ames, IA: Blackwell.

Tibbo, M., Jibril, Y., Woldemeskel, M., Dawo,F., Aragaw, K., and Rege, J.E.O. (2004). Factors Affecting hematological Profile in Three Ethioian Indigenous Goat Breeds. Intern. J. Appl. Res. Vol. 2, No. 4.

Tak, P.C. and Lamba, B.S. (1984). Ecology and Ethology of the Spotted deer: Axis axis (Erxleben) (Artiodactyla : Cervidae. Records of the Zoological Survey of India). Miscellaneous publication (43): 1-26.

Weiss, D.J. and Wardrop, K.J. (2011). Schalm's Veterinary Hematology 6 ed. Wiley Blackwell, Philadelphia. 